\title{
SLC34A2 Gene
}

National Cancer Institute

\section{Source}

National Cancer Institute. SLC34A2 Gene. NCI Thesaurus. Code C101434.

This gene plays a role in phosphate transport. 